\title{
Exciting Times for Legal Scholarship
}

\author{
Jan Vranken
}

\section{$1 \quad$ A crisis of identity?}

Apparently, legal scholarship is presently in the throes of an identity crisis (Smits $2012^{1}$ ). Fundamental doubts are expressed concerning the quality of legal scholarly research. Does it concern itself with the right themes? Are the right questions being asked? Should our approach be revised? What exactly are the criteria for innovative, thorough, and creative legal scholarly research?

One hallmark of an identity crisis is that questions regarding the nature, mission, and methods of our field are not asked by others, but that we ourselves are divided and confused on the issue. I would like to attempt to take stock of and analyse this confusion. That will not be enough to resolve the issue, which is much too complicated for that, but I hope to debunk some of the myths. Some debunking is in order, as the discussion involves plenty of ideology, wishful thinking, tunnel vision and internal contradictions. Derogatory remarks are commonplace. Those involved in the discussion show little ability for horizontal learning: much of what we are discussing was thoroughly debated and evaluated in other fields twenty years ago. We could benefit from that experience, if only because it would enable us to avoid making the same mistakes.

\section{Some remarks concerning terminology}

I will begin this article with a short and fairly narrow description of what is commonly understood to be legal-dogmatic research. In the common law one would call this 'doctrinal legal research', but since my initial, though not exclusive, focus in this paper is on continental Europe I will use the civil law term. Heuristically, it is preferable to avoid cluttering my argument with too many nuances, which will be saved for the next subsection. It will become apparent that a number of characteristics of legal-dogmatic research are subject to much disagreement, then and now, here and elsewhere. This could be one of the causes of the present discord and confusion.

I emphatically state that I am not looking for a debate on definitions. Where my argument touches upon nuances in legal-dogmatic research, I want to avoid extending the definitions just to have all nuances fall within the scope of legaldogmatic research. I am merely trying to show the reality of the situation, which is much more complicated than my narrow description. The proposed innovations should therefore not be contrasted against that narrow description - which 
as an exaggeration is easy to refute - but rather against the present state of affairs. I would prefer to identify this common research merely as legal or legal scholarly research, noting that these are not unified concepts and have any number of shades that are often combined in a given study. However, I will take into account that idiomatic usage is different.

\section{Characteristics of legal-dogmatic research}

Legal-dogmatic research concerns researching current positive law as laid down in written and unwritten European or (inter)national rules, ${ }^{2}$ principles, concepts, doctrines, case law and annotations in the literature. 'Its sources are predominantly those that are thrown up by the legal process: principally statutes and decided cases, supplemented where possible with lawyers' literature expounding the rule and occasionally reflecting on them' (McCrudden 2006, p. 634). This current positive law needs to be "treated" within its own limits - often described from an internal perspective - meaning that its own sources are used as a basis for study, description, explanation and analysis into (conflicting) underlying values, presuppositions and principles, as well as for criticism and any needed proposals for improvement. New developments in European or (inter)national case law and legislation, as well as new developments in society, need to be integrated too. The first concern is improving coherence and consistency, creating and streamlining a system. ${ }^{3}$ However, this is not its ultimate goal: 'Die Grundfunktion der Dogmatik besteht vor allem darin, Gleichheit, Ungleichheit und Ähnlichkeit transparant zu halten', to quote Stürner (2012, p. 11).

All this primarily serves judicial practice, although proposals for improvement are also addressed to legislators or policy-makers. Legal scholarship (legal dogmatics) and judicial practice are commonly equated. An illustrative example would be Sieburgh (2008, p. 13), whose 'the (scholarly) legal debate' is meant to include both. ${ }^{4}$ Another example is Van Schilfgaarde (2010, p. 424-425), who identifies 'the decision' as the core activity of the legal world and adds: 'including legal scholarship. ${ }^{5}$ In the Netherlands, this opinion can be wholly traced back to Paul Scholten (1931, p. vii), who stated in the preface to his Algemeen deel that lawyers should learn to 'take into account the method that private law scholarship uses, to discover why he [the judge] reaches a certain decision and not another and what factors lead to that decision' (italics added). The decision functions as the primary activity of lawyers in private law and the judge is their prototype. Legal research-

2 Some areas of law, such as international public law, also have other forms of written sources, such as reports, documents, explanations, protocols, and papers. These areas also have more unwritten law than others.

3 This is commonly understood as the core activity of researchers (Westerman \& Wissing 2008). I oppose this in 'Methodology of Legal Research' (Vranken 2011).

4 According to its synopsis, this article is an attempt to use the talents that a good lawyer is expected to have as a guide to what law is.

5 Also true for Sieburgh (2008, p. 4): 'The way in which lawyers arrive at their decision is an essential part of both practical and scholarly law.' 
ers approach their work as judges do. Or, even more sharply: legal scholarship is the same as judicial practice, with the only substantial difference being that a judge has to hand down a decision within a limited period of time. The above leads to the unsurprising conclusion that a good lawyer, including legal researchers, should have the same qualifications as a judge: a thorough knowledge of current positive law, a sharply analytical mind, awareness of societal norms, a good sense for (changing) developments in society and the ability to tailor the law to those developments, stolidity, an mature intuition, a good feeling for language and practical wisdom. ${ }^{6}$ Not exactly the kind of qualities expected from scholars in other fields.

\section{The trinity of judicial practice, legal scholarship, and legal education}

The prevailing view is that legal research does not require its own methodology (standards and rules). Legal researchers are abundantly served by using the same methodology as judges, as exhaustively described in literature on judicial reasoning. Both have to base their arguments on the same sources, current positive law, as I described above. And both have to use the same textual analysis, practical argumentation and reasoning to find the best answers to legal questions that arise from existing or theoretical legal conflicts. Sometimes acting at the concrete level of the judge, sometimes more generally as in dissertations and monographs, but their methods always are basically identical. Stürner (2012, p. 12-13) makes a distinction here between 'Gebrauchsdogmatik', which can be very detailed, and 'wissenschaftliche Dogmatik', which is based on (more) general principles and larger contexts. 'Gebrauchsdogmatik' is most strongly present in Germany, where it is more developed compared to for example France and the Netherlands, let alone common law countries. At the European level, private law is also increasingly being studied through methods that go beyond 'Gebrauchsdogmatik' - especially in comments on European directives, the Lando Principles and now the Draft Common Frame of Reference - since it tries to find overarching and foundational principles in the forest of European laws, both as opposed to and interacting with national legal systems. ${ }^{7}$

Universities contribute here as well, as they primarily educate students in the prevailing methods, by training them to resolve cases in the same way that a judge would (Schauer $2009^{8}$ ). Education also places the judicial decision at the centre. This creates a kind of trinity: legal education, judicial practice and legal scholarship all largely operate in the same way. It is a strong bastion. The 'civil effect' of university education carefully guarded by legal practice - even more so in the Unit-

6 Posner (1987) delved into his memories of his education at Harvard to write evocatively on the same subject.

7 See section 5 , below.

8 To Schauer this means: learning how to use sources (rules, precedent, but not literature) and some attention for methods of reasoning and interpretation. This is not substantially different from what Scholten did in 1931. 
ed States than in Europe (Sullivan et al. 2007) - clearly illustrates the trinity. Almost every decade, alarms are raised concerning the limited intellectual baggage that graduates bring to legal practice (Tamanaha 2012). It is curious that curriculums do not introduce their students to literature on judicial reasoning despite the large debt they owe to Scholten (1931, p. vii). Schauer (2009, p. xi) states this is the same everywhere: '(A)lthough most law teachers think that it is important that students know something about the major figures, themes and examples in the canon of legal reasoning, much of this material (...) falls through the cracks in the modern law school.'

Students at universities usually learn how to resolve cases like a judge without reflecting on the methods. Learning by doing, as apprentices learn from their masters. A trend, which continues later in their careers - as legal researchers and judges they rarely consult literature on judicial reasoning either. Inspiring coaches or colleagues are generally more influential.

The Netherlands are not at all unique in setting up judges as role models for legal research and education, and the decision as the core activity of all those concerning themselves with law. It would be more accurate to say that there are few Western countries where prevailing views are different. Judges and their methods for legal reasoning are, almost automatically (Neergaard et al. 2012), ${ }^{9}$ placed at the centre of the search for a 'European Legal Method' as well (Van Gestel, Micklitz \& Poiares Maduro 2012; Van Gestel \& Micklitz 2012). A couple of quotes to illustrate this further (Spitzer 2008, p. 14, 23) for readers who would like to know more: 'Legal reasoning (...) is a kind of reasoning which is adapted to the reaching of decisions for action (...). It is like the kind of reasoning characteristic of (...) any other applied, or practical, art or science (...)' (italics added). And also: 'Most academic law writings (...) concentrate on legal issues and evaluate them in the same way as judges writing opinions' (italics added). ${ }^{10,11}$

\subsection{Criticism}

Until quite recently, the primacy of this type of research was universally acknowledged: legal scholarly research was one and the same as legal-dogmatic research. This idea is presently subject to increasing criticism. Characterisations such as

9 Hesselink (2009) takes a broader view. For a historic perspective see Wendehorst 2011; Fleischer 2011.

10 With the contemporary rise of 'law and ...'-movements, this should lead to more comparison to what other fields have to teach about 'decisions', for example in mathematics or psychology, than is presently the case.

11 Underlying reasons and contexts can vary from country to country, but results are almost invariably the same. See: Posner 1987; 2001; Steiner 2002; Bix 2003; Brownsword 2006; Rubin 2001; Cownie 2004; Twining 1997; Jestaz \& Jamin 2004; McCrudden 2006; Scordato 2008. Extensive, but somewhat didactical, see: Salter \& Mason 2007. 
black letter law, ${ }^{12}$ positivist, or formalist show the declining appreciation. What is the problem? A common opinion in the Netherlands is that private law is more or less finished from a dogmatic perspective. It is felt that the large issues have been resolved. Work is still ongoing, of course, but constitutes no more than fine-tuning and fiddling in the margins. This can be dragged out endlessly, but without yielding much more than a lot of repetition and little vitality or innovation. Legaldogmatic research by definition yields no more new insights. Those who nevertheless cling on to it are forced to fight over marginal issues.

Some writers abroad agree that legal-dogmatic research is hardly dynamic, doesn't really have its own agenda and values technical panache, precise use of terminology, and systematisation over factual research and theoretical development. It sits and waits for case law and draft bills to come along, so those can be commented upon. Rhode (2002, p. 1339) notes that legal-dogmatic research is largely trivial, unoriginal, ephemeral, or irrelevant. For the same reasons, Eric Posner provoked a conference by stating that 'doctrinal research is dead'. ${ }^{13}$ Schlag (2009) says the same, where he brands legal research as 95\% 'case law journalism'.

And yet, legal-dogmatic research has its defenders, who are at least as vehement. ${ }^{14}$ One of the more interesting is Richard Posner, who ceaselessly promotes external perspective, especially law and economics, but also emphasises legal-dogmatic research. 'Disinterested legal-doctrinal analysis of the traditional kind remains the indispensable core of a legal thought', he wrote (1987, p. 777). Twenty years onwards, Posner (2008, p. 211) notes that principles and values are rarely expressed clearly in legislation and jurisprudence and that therefore:

'(t)he messy work product of judges and legislators requires much tidying up, synthesis, analysis, restatement and critique. These are intellectually demanding tasks, requiring vast knowledge and the ability (not only brains, knowledge, and judgment but also Sitzfleisch) to organise dispersed, fragmentary, prolix, and rebarbative materials. Though these tasks lack the theoretical ambition of scholarship in many more typically academic fields, they are vital to the legal system and of greater social value than much of today's esoteric interdisciplinary legal scholarship.'15

In common law this term does not necessarily express disapproval, according to one of the anonymous reviewers of this paper. Holmes (1897, p. 469) already used this term in his 'The Path of the Law'. Holmes' black letter man did not see law as a means to an end, and therefore felt safe in ignoring the social conditions in which the law had to function. Holmes argued for a different approach, combined rather than exclusive: law is both logic and experience. This is the true meaning of the oft-quoted phrase from his book The Common Law (1881): 'law has not been logic: it has been experience', says White (2009).

13 Congress Towards a European Legal Methodology?, Tilburg 10 June 2008.

14 A more extensive overview can be found in Anthony Arnull, quoted by Van Gerven (2008). 
He even argues for the founding of a department of Legal Dogmatism, after promoting a department of Legal Theory in 1987 to counterbalance the dominance that legal-dogmatic research enjoyed at the time (Posner 2008, p. 854-855; 1987, p. 778-779). Not everyone in the US agreed in those days, because a few years later Edwards (1992) warned about the growing chasm between legal education and the legal profession. The complaint is as alive now as it was then (Sullivan et al. 2007; Newton 2010).

In the UK, Peter Birks, as quoted by Waddams (2003, p. 196-197), was one of those who felt that 'traditional legal research and scholarship which criticises, explains, corrects and directs legal doctrine is still and must remain the heart of the law school's research'. The primary function of legal-dogmatic research as mentioned by Stürner (2012, p. 11) is more substantive: 'Gleichheit, Ungleichheit und Ähnlichkeit transparant zu halten', and this is why he feels that '(k)eine Rechtsordnung auf diese Funktion kann verzichten. So besehen gibt es keine Rechtsordnung ohne einen gewissen dogmatischen Grundbestand.' Another important function of legal-dogmatic research is the 'Entlastungsfunktion', because it saves lawyers from having to reinvent the wheel every time they are confronted by a legal question. Rather, they can draw upon an existing framework that has been tried and tested through years of prior experience and study.

There are no exact figures, but for the Netherlands I feel safe in estimating that legal-dogmatic research is still firmly on the throne in the minds of most legal scholars. ${ }^{16}$ Nuances exist, of course. Not everyone defines legal-dogmatic research the same; significant differences and nuances exist. I think the discussion between legal scholars would benefit from a wider acknowledgement of that fact, which I discuss further below.

\subsection{Nuances}

In their defence of legal-dogmatic research, some remain fairly close to the main features I described above. They especially emphasize the internal perspective and the importance of systematization. Others leave some room for external perspectives or data from beyond current positive law or other methods aside from textual analysis and prevailing judicial reasoning. McCrudden (2006, p. 633-635) states that this is the case nearly always and everywhere; although the extent depends on the '(changing) consensus of academic and practising lawyers and judges'. I will restrict myself to the present. The Netherlands is showing a clear tendency towards using some form of empirical data in publications, especially in dissertations. Hervé Tijssen (2009, p. 187) empirically found that one-third of the Dutch dissertations in classical fields he investigated over the last decade included empirical data. Scope and reliability are widely divergent, but it is not just an intuitive taxation of day-to-day practice. The use of other methods than textual analysis and common legal reasoning is an earlier trend and is, it seems to me,

16 In short, the growing criticism aimed at legal-dogmatic research which I mentioned at the beginning of this article may stem from a small minority of voices, but apparently is robust enough to warrant descriptions such as crisis. 
only increasing. Examples are data and insights from law and economics or law and psychology that are sometimes used. This amalgam is called methodical pluralism (McCrudden 2006), and is more common in dissertations and anthologies than it is in journal articles. ${ }^{17}$ Studies of private law from an exclusively legal-economical or legal-psychological viewpoint, nevertheless, are still rare.

A further nuance of legal-dogmatic research concerns its reasoning. I am among those who argue that the debate should not concern itself with legal techniques, but rather with the underlying arguments and facts: legal-political options, thoughts, values and interests. At present, these are usually either omitted entirely or too vague, which means that they cannot be checked and cannot develop. It is quite understandable that a judge works this way, for example because of a lack of time, but it does not mean that scholars should limit themselves in the same way. They especially should be expected to perform such analysis and testing. Their results will undoubtedly find their way into judicial practice once it becomes commonplace. As early as 1925, Learned Hand said the same when he explained what he expected from scholars: development of new methods, presenting new ideas and exploring new areas of law. ${ }^{18}$

Another nuance is the increasing attention for the study of principles and fundamentals, not only at a national level, but also at the European or international level. This type of research, in which comparative law is pivotal, is also a part of legal dogmatism according to its proponents. It merely concerns the larger questions and international correlations within that field. The latter is partly aimed at achieving a higher degree of convergence in Europe. Van Gerven (2008), for example, thinks this is a better approach than codification through the Draft Common Frame of Reference.

Finally, some researchers demand more visionary legal research, which explores new approaches. A poll asking how common this desire was across the various fields - the dogmatic shortfall - showed disappointing results (Van der Heijden 2008). Others call on legal scholars to partly free themselves from their ties to current positive law and to rely more on their imaginations. However, an agenda of what this could or should lead to remains absent. ${ }^{19}$

In short, legal-dogmatic research is far from a unified concept. Perspectives, approaches, or methods that might seem relevant to some, others regard as conflicting with legal-dogmatic research or even as non-legal. For example, the search for 'better' solutions to a problem, a common issue in legal-dogmatic research, is usually not aimed at a better legal-technical foundation but rather at a substantive legal contribution to better fulfil the requirements of society. However, such

17 Another example is Holmes 1897 and Posner 2008. Posner also emphasizes the link between legal dogmatism and other fields, in his case especially law and economics. See also Smits 2012, Siems 2008, and below in section 5 onwards.

18 Quoted by Duxbury 2001, p. 27. More on these nuances in Vranken 2006, Ch. III.

19 My reasons for explicitly not doing so can be found in Vranken 2006, Conclusion. Smits 2012 also fails to develop an agenda. 
questions cannot be answered from a strictly internal dogmatic perspective. Those arguing for more open reasoning also use knowledge and viewpoints that others regard as falling outside the scope of legal dogmatism. The development that private law has seen over, say, the last thirty-five years would have been impossible if legal-dogmatic research had always kept to the limits of an internal perspective and 'the' system.

Of course, a lot of the research was of the type described by Richard Posner, referred to above. This is still the case, in journals even overwhelmingly so, ${ }^{20}$ but the preceding shows that this should not be regarded as indicative for the whole field. Legal-dogmatic research is (has become) significantly more diverse and nuanced. I think the present critics tend to overlook this fact. Rather, it seems to me that they are eager to paint the whole body of legal-dogmatic research with the broad brush of national, small-scale stamp collecting, aimed at educating judicial practice and prone to minutia, repetition, and lack of innovation and energy; more stuffy than exciting. Such accusations give rise to the counterarguments that their qualifications are one-sided, lacking in nuances, over the top or merely untrue and founded on a misinterpretation of both the substance and the value of this type of research. And so, the tone of the debate is set: polarisation. It would seem to me that the discussion would benefit more from recognition of the fact that legal-dogmatic research kept pace with the same developments that inspired the critics, which will be outlined in section 5 and further. The only difference is that the critics draw more radical conclusions, in that they argue for a more radical renewal (and in their view, improvement) of legal scholarly research. Rather than involving myself in the underpinnings of these developments - even though those are quite interesting: see the boxed text - I would like to devote the rest of this article to the proposals that are put forward to improve legal scholarly research. I am forced to use plurals, as the ideas and viewpoints are legion. My outline will necessarily have to be limited to the basics, but that will be sufficient for my intended debunking.

20 Many of the new journals are aimed primarily at the practice of attorneys, company lawyers, notaries, and judges. They are filled with recent case law and its comments. 
Some of the reasons for the developments I outlined are (a) the increasing contextualising of law that I mentioned previously, which means that other elements need to be included aside from exclusively legal ones; (b) the popularity of the 'law and ...'-movements, especially law and economics and law and social sciences, as one of the aspects of the broader movement towards multi-disciplinary research that is visible in other fields as well, because the problems that present themselves are not subject to mono-disciplinary limits. The multi-disciplinary assessment committees of financiers supplement and strengthen this development; (c) the needs of primarily legislators and policy makers (and judges as well) for more advance knowledge concerning the effects and effectiveness of planned measures (or case law) requires knowledge of, among others, social-scientific and economic evaluative research; (d) increasing interest in legislation and regulation as a separate field: what is the best method for regulation at a national and international level? This includes questions of need, usefulness, feasibility, effectiveness of regulation, and possible alternatives to (government) regulation; (e) dissatisfaction with the usual approaches, because those unavoidably lead to a degree of tunnel vision. The need to overcome those limits is nothing new (even though that too eventually leads to tunnel vision); (f) the increased urge to ponder the criteria for proper scientific research, not only for (international) grant applications, but also to cater to research visitations. Also, this is not an exclusively legal phenomenon.

\section{Six new directions}

A rapidly growing group of legal scholars seeks to innovate in legal scholarship primarily, or even exclusively, through internationalisation and Europeanization. $^{21}$ Their main objection against the present state of legal-dogmatic research is that it is largely national in orientation, which is seen as parochial, even when it is supplemented with comparative law, as is increasingly the case. In a globalizing world, national law should no longer be the basis, they feel. The debate should focus on international themes and occur in an international scholarly forum. Publishing in a foreign language, usually in English, is seen as a minimum requirement. Even better would be to endeavour to cooperate with foreign colleagues through networks, study groups or at conferences, and to channel that cooperation into joint publications through publishers that the international

21 The report of the RAE Committee for Legal Scholarship (1995, p. 22) already urged this in 1995. See also the Executive Summary in the report of the RAE Committee (2009, p. 5-7), in which 'national recognized research' is only seen as 2* (out of 4). See currently www.ref.ac.uk/panels/ assessmentcriteriaandleveldefinitions. Note that 'international' in England does not necessarily relate to civil law countries. 
forum deems reputable or, even better, in journals that are internationally referenced and highly ranked. Few law schools in the Netherlands have not yet placed internationalisation at the forefront of their policy.

There is plenty of room for criticism of this movement towards internationalisation and its assumed superiority over legal-dogmatic research, which some see as obvious. I will provide some in section 6 , below, in which I evaluate the innovations in legal scholarship and define my own position. First, I will further elaborate on these new developments.

A second approach to innovating legal scholarship is changing its relation to legal practice. However, what is immediately apparent is that most espousing this approach are not opposed to the traditional practical approach of legal scholarship as such, but rather to the sort of practice that is its focus. They want to shift focus away from judicial practice, towards primarily or exclusively legislative or policy-making practice. Policy-oriented research, which is increasingly conducted at the instigation of third parties and for remuneration, and is then called contract research. To the extent that it is related to private law, this research often concerns an analysis of existing law - for example, whether it would be possible to hold volunteers liable for the damages they cause - as a prelude to recommendations for improving legislation or policy. This research often uses the same methods, arguments and reasoning as doctrinal research, or others when the approach is multi-disciplinary. Possibly there is some room for innovative, out of the box insights. The latter is nice and interesting, but because contract research especially is dependent on the wishes of its client, it has its own, unique set of problems. It is therefore far from certain whether exchanging the agenda of the judiciary for that of legislators and policy makers in this type of research really leads to the intended innovation - improvement - of legal scholarly research. Are those researchers not doing the same as that to which they are opposed, or even more so? At any rate, the superiority of this type of research that is asserted by some is far from certain. I will revisit this in section 6 as well.

A third new direction comprises those who want to get rid of the practical orientation of legal scholarship completely. They are more principled in their objections: legal scholarly research should not, or at least not to the same extent as is presently the case, be dictated by either practical field. Legal scholarship should determine its own agenda, themes and methods independently, at least in part, without regard for immediate benefits for legal practice or society at large, a view to which I subscribe myself. Such fundamental, theoretical research is too rare at present. I do not expect this to change in the foreseeable future. (Financial) leeway for free, unbiased and independent research is diminishing. One of the reasons for this development is that societal relevance, interpreted as practicality, is one of the premier criteria used by research financers, especially for large-scale research. Usually, cooperation from business partners is expressly required. Another reason is that researchers are expected to produce a certain number of publications. Fundamental research is time-consuming and can fail or produce little. This makes the choice easy and unavoidable for some: opting for a safe jour- 
ney instead of blazing new trails with uncertain destinations, if possible subdivided into a couple of short trips. After all, a good idea can be chopped up and served in more than one publication ('salami method'). A third and final reason is even more telling, if possible: legal researchers often use the law as an instrument. For them, the law is a tool to find a solution to problems. Developing theories on explanations, causes, or (behavioural) effects takes a back seat in legal scholarly research.

A quite broad and therefore very diverse (fourth) movement attempts to innovate in legal scholarly research through a multidisciplinary approach, which purportedly leads to better insights and (factual) knowledge. ${ }^{22}$ Law is not unique in that regard. There are few scientific or scholarly fields where this does not occur, or should occur. In law, it is in part due to the contextuality. Knowledge of legal dogmatism is no longer sufficient. The law does not exist in a vacuum: it attempts to regulate and influence human behaviour and social developments. Therefore, it is quite obvious that creating a proper legal system requires knowledge of what motivates people and of the social situation in which they function. As far as I know, this has never been disputed. The only question is how that information can be obtained and here opinions are diverging. A growing awareness that other academic fields involve themselves with questions of people and society as well, and that they could have interesting insights or data to contribute, motivated legal researchers to openly look beyond the limits of their own field. One option is to simply talk to someone from another field and drawing inspiration or information from him or her, another is to seek cooperation with researchers from other fields, similar as to what happens in internationalisation, preferably by having them share their work space and involving them in cooperative projects. ${ }^{23}$

More and more legal researchers turn to multidisciplinary research in their quest for innovation in legal scholarship. Multidisciplinary research is not an unknown factor in law, but is traditionally connected to legal history, legal philosophy, ethics and, more recently. to criminology and legal sociology as well. Another recent development is that legal scholarship is now looking to cooperate with social sciences such as economy and psychology. Law and economics has existed in the United States for some time now and has developed, in all its diversity (Mercuro \& Medema 1997), which presently also includes a variant of law and behavioural economics, into one of the most successful 'law and ...'-movements. In the Netherlands there is a significant development in law and cognitive psychology. An oft-used technique, for example, especially in European consumer directives, is to require producers, resellers, and service providers to inform their consumers. But does that really lead to well-reasoned decisions on their part? Or do their good intentions fall victim to psychological preconceptions or limitations (Giard 2011)? The latter is almost certainly the case, as psychological studies now show.

22 This too was strongly urged by the RAE Committee (1995, p. 23-26). The report by the Cohen Committee (2008) did the same recently.

23 More on the various modalities of this cooperation can be found in, for example, Van Klink \& Taekema 2011 and Siems 2008; 2009. 
The relationship between information and behavior is more complicated and far less linear than is often implicitly assumed in legal causality. Lines are always blurred by environmental factors, such as cognitive and social limitations. Warnings, for example, are often taken by adventurous minds more as an encouragement than as a reason for carefulness. More specific information does not always lead to better decisions either. What can we do and should we do about that in the legal field?

The latter question has become the subject of a profusion of literature (and case law) in common law legal scholarship, a movement that is identified as 'Social Sciences in Law'. ${ }^{24}$ Three questions need to be answered: (1) in which other fields can I find information relevant to my legal question?; (2) how can I determine whether the gathered information is reliable and valid?; (3) assuming the gathered information is reliable and valid, how can I translate it to a legal context - what is its legal meaning? Insights from other fields never have the final word in the legal field. ${ }^{25}$ It would be impossible to apply them to law directly. Translation is always required. Translation is a common term in this context (as it is in comparative law, where the same three basic questions need to be asked and answered).

A fifth movement comprises those who feel that legal scholarship must innovate by performing more empirical research. This more radical approach is not new in the US, where it started with legal realism around the turn of the 20th century, but it never really gained purchase, at least, not in private law (Korobkin 2002; Ulen 2002; Burns \& Hutchinson 2009). Law and economics has also not conducted a great deal of empirical research. Europe has almost no empirical tradition at all, except in socio-legal studies, although one report concluded the situation there also is far from awe-inspiring (Genn, Partington \& Wheeler 2006; Banakar \& Travers 2005; McCrudden 2006; Salter \& Mason 2007 ). It will not be easy to change this fact, if only because it would be quite expensive and because it requires thorough training in socio-scientific methods and techniques. The same can be seen in a new movement that developed recently in the United States: Empirical Legal Scholarship, which is supported almost exclusively by researchers who are not themselves lawyers. They are economists, psychologists, pedagogues and political scientists. The movement is supported by renowned law schools and famous researchers, resulting in a great deal of prestige, money, and power. ${ }^{26}$ It is aimed at nothing but quantitative, large-scale empirical research, aiming to establish extensive databases which are freely accessible to everyone. It is hoped that this will enable legal scholars to develop a (better) factual basis for their state-

24 I wrote an article on this, with many references (Vranken 2009). I refer to that article to keep things short here.

25 Sieburgh (2011, p. 9) writes: 'Empiricism is seen by many, including empirical scientists, as the absolute pinnacle of exactitude' - a statement without any references. References from empirical scientists would be impossible to find, as they would never say something like this.

26 The movement has its own journal (Journal of ELS) and an annual, increasingly popular conference. A sympathetically critical evaluation of ELS can be found in Chambliss 2008. 
ments on legal matters, rather than the vague notions or ideas that they are often based on now. However, the subjects are not always of great importance to Europeans: jury trials, the death penalty, Supreme Court, the voting records of individual judges, appellate courts, discrimination and punitive damages.

I will close this outline of innovative movements by mentioning the sixth one that places emphasis on the methodological aspects of legal scholarly research. This was a marginal issue until recently or, more accurately: because the methodology of legal-dogmatic research was expected to be much the same as the methodology of judges, it was not necessary to discuss it separately. For reasons I touched upon previously (see boxed text) this situation has changed now in the Netherlands as well as abroad. ${ }^{27}$ The same is true of multi-disciplinary and empirical research: methodological questions arise spontaneously. Not only to gather knowledge on what is required in other disciplines for reliable and valid research, or the demands placed on empirical research, but also to adapt the research to the peculiarity of legal scholarship. Multi-disciplinary and empirical research force one to consider these unique demands, more so than internationalisation and comparative law. Legal-dogmatic research is the logical next step. Those who hold to these opinions, including myself, feel that legal-dogmatic research can also benefit from a better methodological foundation. One of the reasons why this is true ${ }^{28}$ is that such a foundation enables operational implementation of the standards set out for proper scholarly research. The standards generally accepted in Dutch legal scholarship are originality (innovation), profundity and thoroughness. Developments in, among others, Belgium and England, are the same or similar. ${ }^{29}$ To be clear: a proper methodological foundation does not guarantee that research will live up to these standards - which will always depend on substantive quality - but it does make it easier to determine when research is not up to standard. It sets a minimum limit. Not everyone agrees however, far from it. Whether or not a methodological foundation for legal-dogmatic research is possible or desirable is a hotly debated issue in the discussion on the crisis in legal scholarship I started this article with. Nevertheless, the 2009 RAE Committee (2009, section 6.3) noted that:

'the situation is in a state of rapid change. Faculties everywhere are voicing their ambition to devote more attention to methodological questions. To this end, they not only encourage their researchers to always justify their research methods in publications and especially in dissertations, but also provide them with the knowledge and insights to do so (...). Although the debate is far from

27 At Tilburg University, the Research Group for the Methodology of Law and Legal Research was founded especially for this purpose in mid-2007 (www.tilburguniversity.edu/research/law/institutes).

28 There is much more, for example quickly switching to a solution without properly charting the problem first, the importance of an assessment framework, collecting and analyzing data, whether or not a clearly formulated research question is necessary, and so on.

29 In England the criteria are 'originality, significance and rigour', but note that they concern all disciplines. For more information, including references, Van Gestel \& Vranken 2010. 
over - and possibly will never be over - the first essential step has been made: the methodology of legal research is no longer assumed, but rather itself a subject of scholarly debate, including in legal scholarship. ${ }^{30}$

\section{Evaluation: plurality over polarity}

I do not believe for a moment that all work is done and that legal-dogmatic research is dead. Far from it, these are exciting times. All this fervor for renewal and pluriformity may be an identity crisis, but who wouldn't want a crisis like that? Obviously we are seeing confusion and divisiveness, and obviously the debate sometimes becomes acrimonious. But I would classify all this squabbling as a sign of unprecedented vitality in the field of legal scholarship, which primarily manifests itself in the rapid growth of viable perspectives for legal scholarly research into questions of positive law. Those questions do exist. In my field of expertise, private law, examples include integrating self-regulation, developing on-line private law, substituting the two-party mental framework for that of multi-layered network relations, integrating European market thinking and individual legal protection, renewing an effective and efficient enforcement through private law in competition (convergence) with criminal, administrative and fiscal law, partly influenced by ETHR and EU, and the development of a multi-level European or transnational private law, coupled with a complete overhaul of the IPR. It would require little effort to expand these large(r) issues into a long list. They are all significant in scope and will require years of effort from large groups of legal researchers to successfully complete. The same will be true for other areas of law.

Multiple approaches are possible: dogmatic - in the nuanced sense I outlined above - international or national as the subject requires, but also multi-disciplinary, empirical or through comparative law. Researchers have different abilities and the requirements of subjects vary. Hybrids exist, of course. In fact, they are luckily increasingly common, at an individual and especially at a programme level. The point I am trying to make is that regardless of the (hybrid) approach that is selected, themes such as those mentioned above will always require fundamental research that has the potential to be highly innovative. Everything but dusty, static stamp collecting. Whether or not the researcher is able to innovate depends on substantive quality, meaning the originality, creativity, thoroughness and soundness of their research. In short: the worth of research does not depend on the type of research that is being conducted but rather on substantive quality. That is the only factor that counts and that can elevate research above the field. This is why Ioppose those who automatically place a higher value on a certain type of research - especially international, multi-disciplinary, empirical, or research not aimed at judicial practice - over (national) legal-dogmatic research. 
All research, regardless of type, must live up to the same quality standards. That is the only way to advance. ${ }^{31}$

A particular criterion can be more problematic for some types of research. For example, legal-dogmatic research aimed at interpreting recent case law or a legal provision has a harder time fulfilling the standard of originality than research into, as Siems (2008) calls it, macro-level questions. ${ }^{32}$ Another example is multidisciplinarianism, which is often extolled because the borderlands between different fields more easily inspire new insights than mono-disciplinary research. This is true, but on the other hand this type of research has a harder time living up to the other standards, such as thoroughness and soundness. Thorough and sound multi-disciplinary research - and empirical research - requires a lot more methodological knowledge and skill than comparative legal or national legal-dogmatic research after all. We are working on gathering that knowledge and those skills in the Netherlands. ${ }^{33}$ An effort I heartily endorse, but I also feel that most of us have a long way to go and should not yet give in to feelings of superiority. ${ }^{34}$

There are more arguments to use something else than the type of research as a quality indicator. The preference for policy-oriented research, for example, is not free from contradiction, wishful thinking and tunnel vision. The idea is that research should not serve judicial practice, because that no longer gives rise to scholarly innovation. However, one of the premier risks of policy-oriented research is that its scholarly significance can become subservient to its practical use. Furthermore, the independence of the researcher can come under threat, not because he wants to give it up himself, but because his research can be used to further any number of policies or political manoeuvres that the researcher cannot foresee or influence. And when the research is performed under contract, the researcher usually does not have a significant say in the research question, the profundity of the research, or the time that can be devoted to it. Does that sound like the sweeping research that would further the cause of legal scholarship? It is just as instrumental and practice-oriented as the research it opposes. Lessons may be drawn from the wide range of experience that other fields have gathered with regards to policy-oriented research. It turns out that the marketplace and the academic world are hardly compatible, although this conclusion appears to fall on deaf ears (Köbben \& Tromp 2003; Köbben 2003; 2008; Lorenz 2008; Van Oostrom 2007).

Another argument not to use the type of research as a quality indicator is the existing overlap. Internationalisation is a cardinal issue at most faculties. Some assign it a fundamentally higher status than national research, as do the systems

31 But see nt. 24.

32 Siems (2008) distinguishes between four forms of originality depending on the type of research.

33 See for an extensive overview Vranken \& Van Dijck 2011.

34 The quality of research of this kind is the subject of much concern in the United States as well. Compare, among others, the harsh criticisms leveled by Epstein \& King 2002. 
for performance measurement used at some faculties. ${ }^{35}$ Why is this so? Research in the fields of international or European law, for example, usually only distinguishes itself from national legal-dogmatic research through its sources and, when it is presented abroad, through its forum and its language, rather than through its methods, approach, or reasoning. Profundity, originality, and creativity are also not intrinsically superior: some research is good and other is mediocre or even bad, just as with all other research. The same is true for much of the research that is published in a foreign language. Why, then, should it be appreciated more? The question what exactly is meant with international legal scholarly research presents itself. Some faculties usually define it as publications on an international subject in an international forum and in a language suitable to that forum, usually English. Less obvious is that comparative legal research, no matter how profound, is not regarded as scholarly significant if it is written in Dutch (as it often is). I see that as a misconception. I believe cultural sociologist Boomkens (2008) said it best when he wrote on the internationalisation of the social sciences. He held that there should be more awareness that internationalisation is not merely a linear process of exchanging, evaluating and cumulating data for international forums, but that it also requires participation, knowledge, study and understanding of the situation in one's own country. Only using the national culture as a basis can the options and effects of internationalisation be properly studied and evaluated.

When applied to law, this means that the movement towards internationalisation requires not only an international orientation, but a well-developed literature and a vigorous debate on national law is absolutely essential as well. The literature and debate are not limited to legal dogmatics, but also include - if these exist empirical multi-disciplinary and comparative law approaches. Comparative law has a unique position, in that it contributes both to a better understanding of national law, as to an understanding of the differences between various legal systems, which makes it an important source for internationalisation. To put it another way: internationalisation is impossible without a thorough (comparative) knowledge of one's own legal system and requires that the literature and the debate on that legal system be of a sufficiently high level. The same is true, in principle, for multi-disciplinary and empirical research, which also requires a legal research question or, in a broader sense, knowledge of issues at stake in law. This does not mean that such research must be of immediate practical relevance, far from it, but I agree with Richard Posner that it eventually should have some direct or indirect connection to judicial practice, legislation or policy: 'Its future (...) depends on the ability (...) of this scholarship to influence practice, rather than merely to circulate their ideas within the sealed network of a purely academic discourse' (Posner 2001, p. 1317). ${ }^{36}$

35 For example the report submitted by the Smits Committee 2007 and Smits 2012. For performance measurement systems in law, compare Van Gestel \& Vranken 2010.

36 He elaborated pointedly: multi-disciplinary research 'is problematic unless subjected to the test of relevance, of practical impact' (Posner 2001, p. 1326). 


\section{Conclusion}

Legal scholarship is subject to a great drive towards innovation, more multiform than ever. That is great. The movements all contribute unique viewpoints, which make each and every one of them of great potential value in the quest for legal innovation. ${ }^{37}$ We should therefore give all movements the space they need to develop themselves, for example searching for the theoretical underpinnings that are presently absent. I am not the only one, nor the first, to argue in favour of multiformity. It has more potential benefits than labelling each others' research as boring, dead and parochial or exaggerated, one-sided, dismissive of the core of the law and other polarising qualifiers. Most movements are still fledgling and have little reason to criticize the others. Legal-dogmatic research too can no longer be dismissed as mere diligent documenting of case law and legislation, a qualification that is given the lie by the large-scale, substantive, thorough and original legal-dogmatic research that also exists.

I expect that most progress will be made in small increments, as is so often the case. Amalgams of different approaches will play the most important role here. A legal-dogmatic study combined with a multi-disciplinary or empirical exploration, for example, in which exploration means that the multi-disciplinary or empirical part should not be immediately expected to be as robust as research that exclusively takes such approach. Sometimes a quick scan is enough, depending on the ends the research aims to achieve. Developments will be quickest when the new perspectives are integrated in case law, which is uncommon at present. Should it happen in the future, judges will have to respond and scholars will react. I think this is still the best boost for renewal in law. The onus to bring this about is on the universities, by making students aware and able to work in this way, which is in line with the desire for a more academic legal training at universities.

\section{References}

\section{Banakar \& Travers 2005}

R. Banakar \& M. Travers (eds.), Theory and Method in Socio-Legal Research, Oxford: Hart Publishers 2005.

\section{Bix 2003}

B.H. Bix, 'Law As an Autonomous Discipline', in: P. Cane \& M. Tushnet (eds.), Oxford Handbook of Legal Studies, Oxford: Oxford University Press 2003, p. 975-987.

\section{Boomkens 2008}

R. Boomkens, Topkitsch en slow science. Kritiek van de academische rede, Amsterdam: Van Gennep 2008.

\section{Brownsword 2006}

R. Brownsword, An Introduction to Legal Research, www.welcome.ac.uk/stellent/ groups/corporatesite (last accessed: 20 September 2012). 


\section{Burns \& Hutchinson 2009}

K. Burns \& T. Hutchinson, "The Impact of "Empirical Facts" on Legal Scholarship and Legal Research Training', The Law Teacher 2009, p. 153-178.

\section{Chambliss 2008}

E. Chambliss, 'When Do Thoughts Persuade? Some Thoughts on the Market for "Empirical Legal Studies"', www.nyls.edu (last accessed: 20 September 2012).

\section{Cohen Committee 2008}

Cohen Committee Report, Duurzame geesteswetenschappen, Amsterdam: Amsterdam University Press 2008.

Cownie 2004

F. Cownie, Legal Academics. Culture and Identities, Oxford: Hart Publishing 2004.

Doorman 2005

M. Doorman, Steeds mooier. Vooruitgang in de kunst, Amsterdam: Bert Bakker 2005.

Duxbury 2001

N. Duxbury, Jurists \& Judges. An Essay on Influence, Oxford: Hart Publishing 2001.

\section{Edwards 1992}

H.T. Edwards, 'The Growing Disjunction between Legal Education and the Legal Profession', Michigan Law Review 1992, p. 34-78.

Epstein \& King 2002

L. Epstein \& G. King, 'The Rules of Inference', Chicago Law Review 2002, p. 1-93.

Fleischer 2011

H. Fleischer, 'Europäische Methodenlehre. Stand und Perspektiven', RabelsZ 2011, p. 700-729.

Genn, Partington \& Wheeler 2006

H. Genn, M. Partington \& S. Wheeler, Law in the Real World. Improving Our Understanding of How Law Works, Londen: The Nuffield Foundation 2006.

Van Gerven 2008

W. van Gerven, Politics, Ethics \& The Law, Legal Practice \& Scholarship, LSE Working Papers 19/2008.

Van Gestel \& Micklitz 2011

R. van Gestel \& H. Micklitz, 'Revitalising Doctrinal Legal Research in Europe. What about Methodology?', in: U. Neergaard et al. (eds.), European Legal Method. Paradoxes and Revitalisation, Kopenhagen: Djoef Publishing 2011, p. 25-73.

Van Gestel, Mickitz \& Poiares Maduro 2012

R. van Gestel, H. Micklitz \& M. Poiares Maduro, Methodology in the New Legal World, Florence, EUI Working Papers Law 2012/13.

Van Gestel \& Vranken 2007

R.A.J. van Gestel \& J.B.M. Vranken, 'Legal Scholarly Papers', NJB 2007, p. 1448-1461. Van Gestel \& Vranken 2010

R.A.J. van Gestel \& J.B.M. Vranken, 'Assessing Legal Research. Sense and Nonsense of Peer Review versus Bibliometrics and the Need for a European Approach', German Law Journal 2010, p. 901-929.

\section{Giard 2011}

R.W.M. Giard (ed.), Judicial Decision Making in Civil Law. Determinants, Dynamics and Delusions, Den Haag: Boom Juridische uitgevers 2011.

\section{Hesselink 2009}

M. Hesselink (2009), 'A European Legal Method? On European Private Law and Scientific Method', European Law Journal 2009, p. 20-45. 


\section{Van der Heijden 2008}

P. van der Heijden, 'Het dogmatisch tekort' ('The Dogmatic Shortfall'), NJB 2008, p. 740 .

\section{Holmes 1881}

O.W. Holmes, The Common Law, Boston: Little, Brown and Company 1881.

\section{Holmes 1897}

O.W. Holmes, 'The Path of the Law', Harvard Law Review 1897, p. 457 e.v.

Jestaz \& Jamin 2004

P. Jestaz \& C. Jamin, La doctrine, Parijs: Dalloz 2004.

Van Klink \& Taekema 2011

B. van Klink \& S. Taekema (eds.), Interdisciplinary Research into Law, Tübingen: Mohr Siebeck 2011.

\section{Köbben 2003}

A.J.F. Köbben, Het gevecht met de engel. Over verheffende en minder verheffende aspecten van het wetenschapsbedrijf, Amsterdam: Mets en Schilt 2003.

\section{Köbben 2008}

A.J.F. Köbben, De tijdgeest en andere ongemakken, Amsterdam: Mets en Schilt 2008.

\section{Köbben \& Tromp 2003}

A.J.F. Köbben \& H. Tromp, De onwelkome boodschap of hoe de vrijheid van de wetenschap bedreigd wordt, Amsterdam: Mets en Schilt 2003.

\section{Korobkin 2002}

R. Korobkin, 'Empirical Scholarship in Contract Law. Possibilities and Pitfalls', University of Illinois Law Review 2002, p. 1033-1066.

\section{Lorenz 2008}

C. Lorenz (red.), If you're so smart, why aren't you rich? Universiteit, markt en management, Den Haag: Boom Juridische uitgevers 2008.

McCrudden 2006

C. McCrudden, 'Legal Research and the Social Sciences', Law Quarterly Review 2006, p. 632-650.

\section{Mercuro \& Medema 1997}

N. Mercuro \& S. Medema, Economics and the Law. From Posner to Postmodernism, Princeton: Princeton University Press 1997.

\section{Neergaard et al. 2011}

U. Neergaard et al. (eds.), European Legal Method. Paradoxes and Revitalisation, Kopenhagen: Djoef Publishing 2011.

Newton 2010

B.E. Newton, 'Preaching What they Don't Practice', South Carolina Law Review 2010, p. 105-156.

\section{Van Oostrom 2007}

F. van Oostrom, Markt en ziel, rede voor de Verenigde Vergadering van de KNAW 2007.

\section{Posner 1987}

R.A. Posner, 'The Decline of Law as an Autonomous Discipline: 1962-1987', Harvard Law Review 1987, p. 761-780.

\section{Posner 2011}

R.A. Posner, 'Legal Scholarship Today', Harvard Law Review 2001, p. 1314-1326.

\section{Posner 2008}

R.A. Posner, How Judges Think, Cambridge (Mass.): Harvard University Press 2008. 


\section{Posner 2009}

R.A. Posner, 'The State of Legal Scholarship Today. A Comment on Schlag', The Georgetown Law Journal 2009, p. 845-855.

\section{RAE Committee 1995}

RAE Committee for Legal Scholarship (Report), Een eigen richting voor het recht, 1995.

\section{Rhode 2002}

D.L. Rhode, 'Legal Scholarship', Harvard Law Review 2002, p. 1337-1361.

\section{Salter \& Mason 2007}

M. Salter \& J. Mason, Writing Law Dissertations. An Introduction and Guide to the Conduct of Legal Research, Edinburgh: Pearson Educated Ltd 2007.

\section{Schauer 2009}

F. Schauer, Thinking Like a Lawyer. A New Introduction to Legal Reasoning, Cambridge (Mass.): Harvard University Press 2009.

Van Schilfgaarde 2010

P. van Schilfgaarde, 'Recht als taalgang', WPNR 2010, p. 420-428.

\section{Schlag 2009}

P. Schlag, 'Spam Jurisprudence, Air Law, and the Rank Anxiety of Nothing Happening', The Georgetown Law Journal 2009, p. 803-835.

\section{Scholten 1931}

P. Scholten, Asser-Scholten. Algemeen deel, Deventer: Kluwer 1931.

\section{Scordato 2008}

M.R. Scordato, 'Reflections on the Nature of Legal Scholarship in the Post-Realist Era', Santa Clara Law Review 2008, p. 353-440.

\section{Sieburgh 2008}

C.H Sieburgh, 'L'art de la distinction: alle oordeel is dat des onderscheids', NJB 2008, p. 3-13.

\section{Sieburgh 2011}

C.H. Sieburgh, 'De schoonheid van de ontdekkingstocht naar gewoon geldend recht', Tijdschrift voor Privaatrecht 2011, p. 1-11.

\section{Siems 2008}

M.M. Siems, 'Legal Originality', Oxford Journal of Legal Studies 2008, p. 148-164.

\section{Siems 2009}

M.M. Siems, "The Taxonomy of Interdisciplinary Legal Research. Finding the Way out of the Desert', (via http://ssrn.com), cross-published in Journal of Commonwealth Law and Legal Education 2009, p. 5-17.

\section{Smits 2012}

J. Smits, The Mind and Method of the Legal Academic, Cheltenham: Edward Elgar Publishing 2012.

\section{Smits Committee 2007}

Smits Committee Report, Naar prestatie-indicatoren voor rechtswetenschappelijk onderzoek, 2007.

\section{Spitzer 2008}

R.J. Spitzer, Saving the Constitution from Lawyers, Cambridge/New York: Cambridge University Press 2008.

\section{Steiner 2002}

E. Steiner, French Legal Method, Oxford: Oxford University Press 2002.

\section{Stürner 2012}

R. Stürner, ,Das Zivilrecht der Moderne und die Bedeutung der Rechtsdogmatik', Juristenzeitung 2012, p. 10-24. 


\section{Sullivan et al. 2007}

W.M. Sullivan et al. (eds.), Educating Lawyers. Preparation for the Profession of Law, San Francisco: Jossey-Bass 2007.

\section{Tamanaha 2012}

B. Tamanaha, Failing Law Schools, Chicago: The University of Chicago Press 2012.

\section{Tijssen 2009}

$\mathrm{H}$. Tijssen, De juridische dissertatie onder de loep. De verantwoording van methodologische keuzes in juridische dissertaties, Den Haag: Boom Juridische uitgevers 2009.

\section{Twining 1997}

W. Twining, Law in Context. Enlarging a Discipline, Oxford: Oxford University Press 1997.

\section{Ulen 2002}

T.S. Ulen, 'A Nobel Prize in Legal Science', University of Illinois Law Review 2002, p. 875-920.

\section{Vranken 2006}

J. Vranken, Exploring the Jurist's Frame of Mind, Deventer: Kluwer Law International 2006.

\section{Vranken 2009}

J.B.M. Vranken, 'Consequenties van een versterking van de rechtsvormende taak van de Hoge Raad. Talrijk, divers en soms vergaand', NJB 2009, p. 1082-1093.

\section{Vranken 2011}

J.B.M. Vranken, 'Methodology of Legal Research', in: M.A.A. van Hoecke (ed.), Methodologies of Legal Research. Which Kind of Method for What Kind of Discipline?, Oxford: Hart Publishing 2011, p. 111-121.

\section{Vranen \& Van Dijck 2011}

J.B.M. Vranken \& G. van Dijck, 'Concluding Remarks in the Special on Law and ...Movements', WPNR 2011, p. 1123-1127.

Waddams 2003

S. Waddams, Dimensions of Private Law, Cambridge/New York: Cambridge University Press 2003.

\section{Wendehorst 2011}

C. Wendehorst, 'Methodennormen in kontinentaleuropäischen Kodifikationen', RabelsZ 2011, p. 730-763.

\section{Westerman \& Wissing 2008}

P. Westerman \& M. Wissing, 'Rechtsgeleerdheid als rechtswetenschap', NJB 2008, p. 503-507.

\section{White 2009}

G.E. White, Introduction of Oliver Wendell Holmes, The Common Law, Working Paper Series of the University of Virginia Law School, nr. 117, 2009. 